\title{
ENGINEER LEADERSHIP IN ORGANIZATIONS AND THE IMPLICATIONS FOR CURRICULUM DEVELOPMENT
}

\author{
Doug Reeve ${ }^{\prime}$, Frieda Daniels, Cindy Rottmann, Robin Sacks, and Adam Wray \\ Institute for Leadership Education in Engineering and Department of Chemical Engineering and Applied Chemistry \\ Faculty of Applied Science and Engineering, University of Toronto \\ doug.reeve@utoronto.ca, frieda.daniels@utoronto.ca, cindy.rottmann@utoronto.ca,robin.sacks@utoronto.ca, \\ adam.wray@utoronto.ca
}

\section{INTRODUCTION}

Historically, Canadian faculties of engineering have excelled at developing the technical competencies of their students, but have been less successful at developing their communication, negotiation, and relationship building skills [4]. In this paper we discuss findings from the first phase of a large scale, mixed-methods study of engineering leadership. In particular, we are investigating: (1) how engineers contribute to leadership in engineering intensive organizations, (2) the defining characteristics of the leader-engineer; and (3) how we can use these findings to augment curriculum and instruction in engineering education.

\section{METHODOLOGY}

The first phase of our study includes data from 9 focus groups and 4 interviews with engineers working in mining, chemical production, engineering consulting, software development and federal politics. We used a grounded theory approach to analyze over 1,000 pages of transcripts [3][6]. In the next phase we completed an extensive survey of the literature. In the third phase we will use a large-scale survey of engineers in the workplace to test our findings and bring more data to bear on questions related to curriculum change.

\section{PRELIMINARY FINDINGS}

We identified three conceptions of leadership that characterize leader-engineers:

\section{Collaborative Optimization}

Building bridges across organizational units to maximize work quality and efficiency. A sample quote: "If you throw me into one of these systems, I am not going to become the leader of the pack, but I am going to make it work better... what happens to me personally is that I get thrown into more and more exciting packs. It's like [my colleagues] know that whenever [I am] in one of these groups, [I] will make it work so much better."

\section{Technical Mastery}

Modeling technical excellence and passing on experientially gained insights. A sample quote:

"The real leader where the rubber meets the road is your tech lead."

\section{Organizational Innovation}

Operationalizing their vision for an engineeringintensive organization. A sample quote:

"Another thing engineers do, if they are innovative, is that they can think outside the box and they aren't just a cog or a store-bought engineer. They are actually identifying opportunities, they are seeing things and they are trying to establish best practices and they can actually help plan to get from point $\mathrm{A}$ to point $\mathrm{B}$ and consider everything in between."

We found that skills, traits, and attributes related to Daniel Goleman's model of Emotional Intelligence are the ones deemed among the most essential to workplace success by practitioners [4]. In particular: initiative; empathy; teamwork and collaboration; conscientiousness; oral communication and adaptability.

Our findings suggest that there is significant need for curriculum enhancement in the area of professional development and personal and relationship skills to facilitate the development of leadership capability in engineers.

\section{Acknowledgements}

This study was conducted with support from four partner companies, ERCO Worldwide, Google Canada, Hatch, and Vale, and the Strategic Fund of the Dean of Faculty of Applied Science and Engineering, University of Toronto. The authors are also grateful to the many participants of the focus groups and interviews.

\section{References}

[1] Ernst, E. \& Peden, I. (1998). Realizing the new paradigm for engineering education: Proceedings. Engineering Foundation Conference, New York, NY June 3-6, 1998. 
[2] Fromm, E. (2002). The changing engineering educational paradigm. Bernard M. Gordon Lecture.

National Academy of Engineering. Delivered October, 6th 2002. Retrieved from

http://www.jee.org/2003/april/767.pdf.

[3] Glaser, Barney, \& Strauss, Anselm. (1967). The

Discovery of Grounded Theory. Chicago: Aldine.

[4] Goleman, D. (2000). Leadership that gets results.

Harvard Business Review. March-April 2000. pp. 1-15.

Glaser, B \& Strauss, A. (1967). The discovery of grounded theory. Chicago: Adeline.

[5] Lamancusa, J. S., Zayas, J. L., Soyster, A. L., Morell, L., \& Jorgensen, J. (2008). The learning factory: Industrypartnered active learning. Journal of Engineering

Education, 97(1), 5-11. Retrieved from

$\mathrm{http} / /$ search.proquest.com/docview/217965776?accountid $=14771$

[6] Pandit, N. (1996). The Creation of Theory: A recent application of the grounded theory method. The Qualitative Report 2(4). Retrieved from www.nova.edu/ssss/QR?QR2-4/pandit.html 